УДК 78.071.2

DOI $10.15421 / 22183$

Тулянцев Андрій Анатолійович, кандидат мистецтвознавства, дочент, професор кафедри „ІІсторія та теорія музики” Дніпропетровської академії музики ім. М. Глінки тел. (093) 723 - 45 - 15 e-mail: ksb2008dnepr@rambler.ru

Сазонова Марія Вікторівна, магістрант кафедри „Музичне мистецтво естради” Дніпропетровської академії музики ім. М. Глінки тел. (063) 858 - 06 - 27 e-mail: zabavadavis@i.ua

\title{
БЕНД LELEKA BERLIN: УКРАЇНСЬКИЙ ФОЛЬКЛОР І ДЖАЗ
}

Мета статті полягає у розкритті індивідуальності виконавського стилю етно-джаз-бенду Leléka berlin, у виявлені особливостей синтезу його професійних музично-сценічних взаємодій, а також в аналізі професійних якостей відповідного інструментально-вокального виконавства. 3 персоною Вікторії Антон та іï колег-інструменталістів можна визначити актуальну цінність міжнародної творчої діяльності етно-джаз-бенду Leléka berlin, зрозуміти його специфіку, окреслити професійні можливості, розкрити особливості творчих пошуків сучасних музикантів, а також з'ясувати умови ефективної діяльності такого квартету, як етно-джаз-бенд Leléka berlin у сучасному соціумі. Методологія дослідження зумовлюється емпіричною природою наукової розвідки, яка формує превалювання у статті таких дослідницьких методів як спостереження та узагальнення. Саме ці методи дозволяють, перш за все, розкрити творчу індивідуальність етноджаз-бенду Leléka berlin. Наукова новизна. Вперше в історії українського музикознавства зроблена спроба розглянути феномен етно-джаз-бенду Leléka berlin, який було створено у 2016 році. Аналіз взаємовпливу інструментального та вокально-сценічного напрямків у сучасному естрадному мистецтві виявив актуальні 
особливості концертної діяльності етно-джаз-бенду Leléka berlin, як міжнародного музичного явища та сценічного видовища. Висновки. Зроблено музикознавчий аналіз, пов'язаний 3 обгрунтуванням інструментально-вокальної моделі етно-джазбенду Leléka berlin, що обумовлює фольклорне продовження в сучасному міжнародному естрадному виконавстві. Вокальноінструментальна ансамблевість, що підпорядковує собі всю концертну та гастрольну діяльність, - основа дієвого функціонування етно-джаз-бенду Leléka berlin, на якому будується вся система його критеріїв сучасної музичної пропаганди українського фольклору. Концерти, гастролі, виступи етно-джазбенду Leléka berlin на Магдебургзькому міжнародному театральному фестивалі підтверджують той факт, що виконавці вкладають у гру та спів власне світовідчуття, своєрідно розкривають образний світ українського фольклору у його джазовій обробці.

Ключові слюва: етно-джаз-бенд, квартет, солістка, інструменталіст, фортепіано, хор, контрабас, ударні інструменти, вокал.

Тулянцев Андрей Анатольевич, кандидат искусствоведения, доцент, профессор кафедры „История и теория музыки” Днепропетровской академии музыки им. М. Глинки

Сазонова Мария Викторовна, магистрант кафедры „Музыкальное искусство эстрады” Днепропетровской академии музыки им. М. Глинки

\section{Бенд Leleka Berlin: украинский фольклор и джаз}

Цель статьи состоит в раскрытии индивидуальности исполнительского стиля этно-джаз-бенда Leléka berlin, в выявлении синтеза его профессиональных музыкально-сценических взаимодействий, а также в анализе профессиональных критериев данного художественного инструментально-вокального исполнительства. С персоной Виктории Антон и ее коллегинструменталистов можно определить актуальную ценность международной творческой деятельности этно-джаз-бенда Leléka berlin, понять его специфику, обозначить определённые профессиональные возможности, раскрыть особенности творческих поисков современных музыкантов, а также выяснить условия 
эффективной деятельности такого квартета как этно-джаз-бенд Leléka berlin в современном социуме. Методология исследования обуславливается эмпирической природой научной разработки, которая формирует превалирование в статье таких исследовательских методов как наблюдение и обобщение. Именно эти методы позволяют, в первую очередь, раскрыть творческую индивидуальность этно-джаз-бенда Leléka berlin. Научная новизна. Впервые в истории украинского музыкознания сделана попытка рассмотреть феномен этно-джаз-бенда Leléka berlin, который был создан в 2016 году. Анализ взаимодействия инструментального и вокально-сценического направлений в современном эстрадном искусстве опеределил актуальные особенности концертной деятельности этно-джаз-бенда Leléka berlin как международного музыкального явления и сценического зрелища. Выводы. Сделан музыковедческий анализ, связанный с обоснованием инструментально-вокальной модели этно-джазбенда Leléka berlin, что обуславливает фольклорное продолжение в современном международном эстрадном исполнительстве. Вокально-инструментальная ансамблевость, которая подчиняет себе всю концертную и гастрольную деятельность, - основа действенного функционирования этно-джаз-бенда Leléka berlin, на которой выстраивается вся система его критериев современной музыкальной пропаганды украинского фольклора. Концерты, гастроли, выступления этно-джаз-бенда Leléka berlin на Магдебургском международном театральном фестивале подтверждают тот факт, что исполнители привносят в игру и пение собственное мировоззрение, своеобразно раскрывают образный мир украинского фольклора в его джазовой обработке.

Ключевые слова: этно-джаз-бенд, квартет, солистка, инструменталист, фортепиано, хор, контрабас, ударные инструменты, вокал.

Tulyantsev Andrey, $\mathrm{PhD}$ in Arts, docent, professor of the „History and Theory of Music” chair, Dnipropetrovsk Music Academy after Mikhail Glinka

Sazonova Maria, graduate student of the chair „Musical art of variety" of Dnipropetrovsk Music Academy after Mikhail Glinka

Bend Leleka Berlin: Ukrainian folklore and jazz 
The purpose of the study is disclosing of the individuality for the performing style concerning the ethno-jazz-band Leléka berlin, revealing the synthesis of its professional musical and scenic interactions, as well as analyzing of the professional criterions for the artistic quality of instrumental-vocal performing. With Victoria's person Anton and her fellow instrumentalists the making possible to determine the actual value of the international creative activity of the ethno-jazzband „Leléka berlin”, to understand its specificity; to identify the professional opportunities, to reveal the features of creative searches of the modern musicians as well as to find out the conditions for effective activity of such a quartet as ethno-jazz-band „Leléka berlin” in the contemporary society. The methodology of the investigation is conditioned by empirical nature of scientific elaboration, which forms the precondition in the article of such research methods as observation and generalization. It is these methods allow, primarily, identifying of the creative individuality for the ethno-jazz-band „Leléka berlin”. Scientific novelty. For the first time it was made an attempt to examine the phenomenon of ethno-jazz-band „Leléka berlin” in the history of Ukrainian musicology, which was created in 2016. The analysis of the interaction of instrumental and vocal-scenic trends in contemporary pop art determined the actual features of the ethno-jazz-band „Leléka berlin” concert activity as an international musical phenomenon and a scenic spectacle. Conclusions. The musicological analysis connected with the substantiation of instrumental-vocal model of ethno-jazz-band Leléka berlin was made, which determines the folklore continuation in the modern international variety performance. Vocal-instrumental ensemble, which subordinates all concert and tour activity, is the basis of the effective functioning of the ethno-jazz-band „Leléka berlin” on which the whole system of its criteria of modern musical propaganda of Ukrainian folklore is built. Concerts, tours, performances of ethno-jazzband „Leléka berlin” at the Magdeburg International Theater Festival confirm that fact that performers bring their own worldview into the game and singing, they open the figurative world of Ukrainian folklore in its jazz processing peculiarly.

The key words: ethno-jazz-band, quartet, soloist, instrumentalist, piano, chorus, double bass, drums, vocal. 
Постановка проблеми. Оновлення сучасних естраднопісенних напрямків пов'язане насамперед зі змінами у сфері видовищного ринку. Естрадно-пісенна атмосфера в Україні 2000-х - 2018-х років вже пройшла кризові випробування та орієнтується на стабілізацію видовищного ринку, професійну майстерність солістів та колективів. У 1990-х роках в українській пісенній естраді відбулась розробка нових жанрових, стильових і, в цілому оновлених тематичних зон, вивчення яких є майже недослідженою сферою у сучасному музикознавстві.

Актуальність дослідження. Відзначимо, що до стилістичного збагачення сучасної музично-інтонаційної сфери додається й усвідомлення стилістики іноземних музичних гуртів, поп-, джаз- та рок- напрямів. Утверджується стилістика, яка інтегрується в українське фольклорно-творче підгрунтя. Нові тенденції, що визначились у розвитку української пісенної естради породили дискусії 3 питань інтенсивного впровадження таких новітніх стилістик, як фольк-рок (,Cool before”), альтернативний рок („Армада”), європоп та євроденс („Аква Віта”), бойз-бенд („Льомі Льом”), хіп-хоп („Вхід у змінному взутті”, „Гринджоли”). Також розрізняються: 1 - різноманітні прояви стилістики $\mathrm{R} \& \mathrm{~B}$ (,ритмічна музика” у вигляді репу, хіп-хопу, у синтезі із роком, поп-музикою та навіть шансоном й естрадним романсом - „Воплі Відоплясова”, „SunSay”, „Onuka”, „Крихітка Цахес”, „5’nizza”, „ТНМК”); 2 - фольк-рок із „украпленнями” елементів романсової стилістки (гурти „Скрябін”, „Океан Ельзи”, „Бумбокс”); лірична естрадна пісня з елементами танцювальних ритмів (Руслана, Ірина Білик, Віталій Козловський, Наталя Могилевська, Джамала, Monatiк, Юрко Юрченко, Pure: Pur, Dakh Daughters, Час та скло, Melovin, Tayana).

3 дистанції часу стало зрозуміло, що творчий результат $\epsilon$ основою музичних досягнень. Закономірним $\epsilon$ те, що все малозапитане видовищним ринком відпадає, залишаються лише найяскравіші творчі фігури, дослідження яких i формує актуальність заявленою теми.

Огляд літератури. Питання своєрідності взаємодії українського фольклору 3 найвідомішими напрямами джазової, естрадної музики майже не розглядались у науково-дослідницькій сфері сучасного музикознавства. Інформація подібної тематики 
висвітлювалась переважно у незначних фактах довідкової літератури що, на жаль, не входить до переліку фундаментальних наукових розвідок з окресленої тематики.

Мета статті - здійснити музикознавчий аналіз найбільш специфічних особливостей синтезу фольклору та джазу у творчості відомого мистецького колективу етно-джаз-бенд Leléka berlin.

Об'єктом дослідження постає творча діяльність етно-джазбенду Leléka berlin у синтезі його професійних музично-сценічних взаємодій, а предметом - особливості поєднання українського фольклору і сучасної джазової музики.

Виклад основного матеріалу. Культурний феномен сучасності - у центрі уваги глядацької аудиторії сьогодення опинився мультикультурний проект Leléka berlin. Це - чотири музиканти 3 України, Польщі та Німеччини, що сплітають старовинні українські мотиви із сучасним джазом, додаючи своїх музичних та культурних особливостей.

Відтак, це саме той випадок, коли зацікавленість джазом та досконалою красою українського мелосу - непідробно справжня. Склад гурту: джазові музиканти Роберт Вінрьодер - фортепіано (Німеччина), Томас Коларчик - контрабас (Польща), Якоб Хегнер ударні інструменти (Німеччина), Вікторія Антон - вокал (Україна).

Leléka народилась у Берліні на початку 2016 року, а у травні того ж року музиканти виступили наживо в Акторському Домі у Магдебурзі, на одній сцені з Dakh Daughters. У вересні 2017 року гурт отримав перемогу на фестивалі етнічної експериментальної музики Creole - Global Music Contest. Бice Акаме (Bisseh Akamé) 3 Universal Music Group на церемонії нагородження Global Music Contest про Leléka висловила наступне: „Ми обрали цей гурт тому, що вони за допомогою оригінальної комбінації стилістичних засобів викликали у публіки неочікувану емоційну реакцію. Leléka різноманітна, щира, смілива та багатогранна. Співачка прекрасний оповідач. Вона змогла дістати зі свого інструмента голосу - дійсно все. Я люблю госпел, але ця музика має для мене тепер нове значення. Я б назвав це ,український госпел” [3].

Специфічною рисою колективу є берлінський джаз на основі українського мелосу. Солістка та організатор колективу - українка Вікторія Антон. Вона народилась у місті Першотравенськ Дніпропетровської області. 3 дитинства брала участь у різних 
музичних заходах: вокальні, композиторські конкурси, музична школа по класу фортепіано. Отримала також хореографічну підготовку. Закінчивши Київський національний університет театру, кіно і телебачення ім. І. Карпенка-Карого, Вікторія Антон працювала актрисою у Київському академічому „Молодому театрі” два роки. Потім разом із чоловіком, актором Себастьяном Антоном, переїхала до Берліна. Себастьян Антон - актор, перекладач, зіграв роль німця у фільмі „Чужа молитва” (режисер Ахтем Сейтаблаєв). Берлін - відкрите місто для створення музичних проектів. Тому, живучи у Німеччині, Вікторія Антон продовжила навчання на курсах джазу, де співала українські пісні. Згодом створила бенд Leléka berlin.

Отримавши запрошення на театральний фестиваль у Магдебурзі, Вікторія Антон вибрала назву для бенду - „Лелека”. Співачка вважає, що назва має бути символічною: птахи лелеки приносять весну, дітей та вдачу. Цей музичний проект надає українським пісням у Німеччині нове сценічне життя.

„Народний твір - анонімний, що побутує усно, знаходиться у процесі постійної змінності. Із однієї пісенної „зав’язі” розростаються грона варіантів, які успадковують семантичні й конструктивні елементи свого першоджерела, не залишаючись водночас незмінними. Специфічне нефіксоване протягом століть побутування фольклору дає простір для утвердження нової змістовної ідеї у безлічі варіантів та жанрових втілень. Це визначило тенденцію до „стискування” часу, широкої типізації ідей, сюжетів. У цьому велика сила впливу фольклору, його неперехідне значення. Чим давніший твір, тим більша ймовірність його варіантних розщеплень, жанрових трансформацій. У початкових фазах розвитку народної творчості пісенні ,зав'язі” не могли бути надто різноманітними і численними, 3 огляду на скромний інтелектуальний i слуховий досвід людей. 3 часом, їх кількість і якість зростає" [2, 32].

Ідеї, закладені в одній із концепцій С.Й. Гриці, дістали найповнішу розробку в інструментально-вокальній практиці етноджаз-бенду Leléka berlin. Серед творів, які становлять репертуар етно-джаз-бенду Leléka berlin - „Гаданочка”, „Ой, там, на товчку”, „Ой, в коло”, „Колисанка”. 
Вкрай важливо усвідомлювати й своєрідності мистецькотворчих пошуків етно-джаз-бенду Leléka berlin. Процес інтонаційно-образної трансформації охопив i творчість цього музичного колективу. Його творчий хід $\epsilon$ історично зумовленим сценічно-видовищними оновленнями, характерними для сучасної естради Німеччини та України. Це: виступи на невеличких камерних сценах клубів, відкритих майданчиках фестивалів, які знаходяться на значній відстані від публіки; відсутність декорацій та етнографічних українських костюмів, загальне світлове оформлення сцени. Маємо також акцентувати й мовну проблему: образні та метафоричні назви та тексти українських фольклорних творів мають бути грамотно перекладеними на німецьку мову.

Безумовно, на перший план виходить персона Вікторії Антон. Сильний голос гарного м'якого тембру в поєднанні з музичністю, правдивістю і щирістю виконання дали змогу співачці відтворити у пісенних мініатюрах поетичні узагальнені образи українських жінок. Голос співачки - найнадійніший інструмент, що може звучати i насичено, і м'яко-матово, холоднувато, і „флейтово”: ніжно, світло, променисто.

Голос Вікторії Антон забарвлює образ. Співачка знаходить різноманітні емоційно-психологічні засоби вираження й багатство інтонацій для передачі трагедії матері у пісні „Пливе кача”, яка тужить за загиблим сином. Емоційне і водночас заглибленофілософське звучання голосу $\mathrm{B}$. Антон органічно увійшло у вокально-інструментальну дію концерту, привнесло у нього важливі ідейно-смислові акценти, виявило схвильоване, пристрасне ставлення співачки до подій, про які йдеться у пісні.

Глибокий народно-етнографічний оптимізм творів „Гаданочка”, „Ой, там, на товчку”, „Ой, в коло”, „Колисанка” дістали у виконанні В. Антон яскраве і переконливе вираження. Підстави для подібного тлумачення давала сама музика - весела, динамічна, темпераментна та гостросучасна. Етно-джаз-бенду Leléka berlin вдалось відтворити ¥іi яскраву образність, тонкий гумор, ритмічне багатство. Утверджується використання синтезу фольклору та джазу як головного музично-драматургічного фактору. Широке залучення інтонаційної сфери джазу із іi загострено-експресивною музичною мовою, принципами звукоутворення (своєрідна мелізматика, глісандо), суто джазова 
ритміка, імпровізаційність розвитку, наскрізне проведення пісенного лейтмотиву характерні для концертів-вистав, які втілює етно-джаз-бенд Leléka berlin.

Висновки. Вікторія Антон - виконавиця інтелектуального плану. Вона не покладається лише на природу та інтуїцію, а завжди багато працює, вивчає документи i джерела, шукає власне неповторне відчуття образу. Співачці властиве навіть режисерське бачення пісні, яке їй підказує інтуїція. I ця інтуїція, а ще професійний смак і досвід, уміння узгодити творчі бажання 3 можливостями етно-джаз-бенду Leléka berlin та актуальне відчуття потреб сучасного німецького й українського слухача, допомагають цим музикантам долати виконавсько-сценічні труднощі. Разом 3 виконавством набирає творчої сили і художньої самобутності міжнародне інструментально-вокальне мистецтво, яке успішно репрезентує етно-джаз-бенд Leléka berlin. Розширюючи й збагачуючи репертуар, квартет впевнено вийшов на шлях сучасної пропаганди української народної пісні у Німеччині, успішно утверджуючи своєрідне та яскраве міжнародне мистецьке кредо.

\section{Перспектива дослідження визначається можливістю} проведення порівняльного аналізу творчого доробку етно-джазбенду Leléka berlin з іншими подібними мистецькими колективами як з України, так і з інших держав.

\section{Список використаних джерел і література:}

1. Верменич Ю.Т. Джаз. История. Стили. Мастера. Санкт-Петербург: Планета музыки, 2007. 608 с.

2. Грица С.Й. Мелос української народної епіки. Київ: Наукова думка, 1979. $245 \mathrm{c}$.

3. Leléka berlin. http://www.facebook.com/lelekaberlin/ (дата звернення 12.09.2017).

\section{References:}

1. Vermenich, Ju.T. (2007). Jazz. History. Styles. Masters. Sankt-Peterburg: Planeta muzyki [in Russian].

2. Hrytsa, S.Y. (1979). Melos of the Ukrainian folk epic. Kyiv: Naukova dumka [in Ukrainian].

3. Leléka berlin, (2017). [Electronic resource]. Retrieved from http://www.facebook.com/lelekaberlin [in English]. 